\title{
Spatiotemporal Variations and Contributing Factors of Air Pollutant Concentrations in Malaysia during Movement Control Order due to Pandemic COVID-19
}

\author{
Zulfa Hanan Ash'aari', Ahmad Zaharin Aris ${ }^{1 *}$, Eliani Ezani', \\ Nurfatin Izzati Ahmad Kamal ${ }^{1}$, Norlin Jaafar ${ }^{3}$, Jasrul Nizam Jahaya ${ }^{3}$, \\ Shamsuri Abdul Manan ${ }^{3}$, Muhamad Firdaus Umar Saifuddin ${ }^{1}$ \\ ${ }^{1}$ Department of Environment, Faculty of Forestry and Environment, Universiti Putra Malaysia, 43400, UPM Serdang, \\ Selangor, Malaysia \\ ${ }^{2}$ Department of Environmental and Occupational Health, Faculty of Medicine and Health Sciences, Universiti Putra \\ Malaysia, 43400 UPM Serdang, Selangor, Malaysia \\ ${ }^{3}$ Department of Environment, Wisma Sumber Asli, Persiaran Perdana, 62574 Federal Territory of Putrajaya, Malaysia
}

\begin{abstract}
The restriction of daily and economic-related activities due to COVID-19 pandemic via lockdown order has been reported to improve air quality. This study evaluated temporal and spatial variations of four major air pollutant concentrations across Malaysia before (March 4, 2020-March 17, 2020) and during the implementation of different phases of Movement Control Order (MCO) (March 18, 2020-May 12, 2020) from 65 official regulatory air quality stations. Results showed that restriction in daily and economic activities has remarkably reduced the air quality in all sub-urban, urban, and industrial settings with relatively small contributions from meteorological conditions. Overall, compared to before MCO, average concentrations of $\mathrm{PM}_{2.5}, \mathrm{CO}$, and $\mathrm{NO}_{2}$ reduced by $23.1 \%, 21.74 \%$, and $54.0 \%$, respectively, while that of $\mathrm{SO}_{2}$ was constant. The highest reduction of $\mathrm{PM}_{2.5}, \mathrm{CO}$, and $\mathrm{NO}_{2}$ were observed in stations located in urban setting, where $63 \%$ stations showed significant reduction $(p<0.05)$ for $\mathrm{PM}_{2.5}$ and $\mathrm{CO}$, while all stations showed significant reduction in $\mathrm{NO}_{2}$ concentrations. It was also revealed that $70.5 \%$ stations recorded lower concentrations of $\mathrm{PM}_{2.5}$ during $\mathrm{MCO}$ compared to before $\mathrm{MCO}$, despite that high numbers of local hotspots were observed simultaneously from NASA's Moderate Resolution Imaging Spectroradiometer (MODIS). Spatial analysis showed that the northern part of Peninsular had the highest significant reduction of $\mathrm{PM}_{2.5}$, while the highest of $\mathrm{NO}_{2}$ and $\mathrm{CO}$ reduction were found in stations located in the central region. All pollutants exhibit similar diurnal trends when compared between pre- and during MCO although significant lower readings were observed during MCO. This study gives confidence to regulatory body; the enforcement of strict air pollution prevention and control policies could help in reducing pollution.
\end{abstract}

Keywords: Aerosols; Anthropogenic emissions; Area sources; Mobile sources; Stationary sources.

\section{INTRODUCTION}

Coronavirus Disease 2019 or COVID-19 is an infectious disease caused by severe acute respiratory syndrome coronavirus 2 (SARS-CoV-2) that impacts respiratory infections in humans (WHO, 2020a). Common symptoms of COVID-19 include fever, cough, myalgia, and fatigue (Chan et al., 2020). COVID-19 first case was reported in December 2019 in Wuhan, China, and to date, COVID-19 is affecting

\footnotetext{
* Corresponding author.

Tel.: +603-97697455

E-mail address: zaharin@upm.edu.my
}

216 countries globally (Pascarella et al., 2020; WHO, 2020b). The World Health Organization (WHO) declared COVID-19 outbreak a Public Health Emergency of International Concern on January 30, 2020 due to widespread global infection (WHO, 2020c). As of August 6, 2020, approximately, 18.6 million coronavirus' cases with total 702,642 deaths have been reported globally. Highest cases were recorded in United States $(4,728,239$ cases) followed by Brazil with 2,801,921 cases (WHO, 2020b). In Southeast Asia, total 2,360,721 cases were reported as of August 6, 2020 with $2.2 \%$ death.

The first case of COVID-19 in Malaysia was reported in January 2020 and till date (August 6, 2020), Malaysia was reported to have a total of more than 9,000 cases. To prevent the spread of the virus, Malaysia announced its first 
Movement Control Order (MCO P1) on March 18 until March 31, 2020. During MCO, all mass gathering is prohibited; all business services and educational institution need to be closed except for essential ones (e.g., water, electricity, energy, telecommunications, postal, transportation, banking, health services, airport, safety, defense, cleaning, retail, and food supply), and all citizens have been prohibited from leaving the country with foreigners also restricted from entering the country (Bunyan, 2020; Md Shah et al., 2020; Prime Minister Office, 2020a). Violators of the MCO are subject to a fine of RM1,000 and a maximum of 6 months imprisonment (Ahmad, 2020). The second MCO (MCO P2) continues from April 1 until April 14, 2020, followed by the third phase of the MCO (MCO P3) from April 15 until April 28, 2020, and the fourth MCO (MCO P4) starts from April 29 until May 12, 2020. Nonetheless, if numerous cases were detected within an area, the area will be subjected to stricter order called Enhanced Movement Control Order (EMCO) for 14 days. Residents within the area subjected to EMCO are prohibited from exiting their homes and adequate food supplies will be provided by the authorities. All businesses will be shut down and all roads leading to the area will be blocked (Bernama, 2020a). On May 4, 2020, the Prime Minister of Malaysia then announced the Conditional Movement Control Order (CMCO) where some businesses, public, and private services are allowed to restart with certain restrictions (Bernama, 2020b). The enforcement of the MCO unprecedentedly may create unique conditions for assessing the effect of local anthropogenic activities, especially on air pollution.

Air quality reductions attributed to COVID-19 have been commonly discussed around the world. Collivigneralli et al. (2020) found that lockdown in Italy did help in improving the air quality in meteorologically comparable periods. Sharma et al. (2020) reported maximum reduction in $\mathrm{PM}_{2.5}$ concentration in most regions in India due to lock down, whereas Dantas et al. (2020) found that $\mathrm{CO}, \mathrm{NO}_{2}$, and $\mathrm{PM}_{10}$ concentrations reduced during lockdown in Rio de Janeiro, Brazil. A study by Chen et al. (2020) found that $\mathrm{PM}_{2.5}, \mathrm{PM}_{10}$, $\mathrm{SO}_{2}, \mathrm{NO}_{2}$ and $\mathrm{CO}$ concentrations during lockdown period in 366 urban area in mainland China fell as much as 14\%, 15\%, $12 \%, 16 \%$, and $12 \%$ respectively from the previous year level. A similar decreased was also reported in East China in first quarter of 2020 with highest reduction of $\mathrm{CO}$ and $\mathrm{NO}_{2}$ were $20 \%$ and $30 \%$ respectively compared to first quarter of 2019 due to reduction in human activity, transport restriction, and commercial demand (Filonchyk et al., 2020).

Considering Malaysia, concentration of air pollutants particularly particulate matter (PM) is strongly influenced by the monsoons (Khan et al., 2015). While PM concentration was primarily affected by transported-regional emissions during the dry season in the country, it was influenced by local biomass burning, traffic, and industries in other seasons (Ash'aari, 2014; Khan et al., 2015). A preliminary research by Abdullah et al. (2020) used converted $\mathrm{PM}_{2.5}$ concentrations from air pollution index (API) data and reported a reduction up to $58 \%$ in the concentration data across Malaysia during MCO. However, high variations in $\mathrm{PM}_{2.5}$ concentrations found in the study led to an interesting question whether the location of the stations in different settings such as sub-urban, urban, industrial, local, and background will contribute to the reduction. Another study by Mohd Nadzir et al. (2020) reported a reduction between 20 and $59 \%$ of $\mathrm{PM}_{2.5}$ concentrations during periods of MCO observed from low-cost sensors deployed within the urban central region in Petaling Jaya district. However, the study also reported an increase in $\mathrm{PM}_{10}$ and $\mathrm{PM}_{2.5}$ concentrations in one of their monitoring stations due to the transport emissions from other regions, local burning activities, and the highway construction nearby. A study by Suhaimi et al. (2020) showed that $\mathrm{PM}_{10}$, $\mathrm{SO}_{2}, \mathrm{NO}_{2}$, and $\mathrm{CO}$ concentrations were reduced between 5 and $50 \%$ on the first week of MCO in urban setting. Also, a study by Kanniah et al. (2020) revealed that the highest reductions were observed in $\mathrm{NO}_{2}$ concentrations in Malaysian urban region.

Motivated by the above enormous potential sources subjected to the influence of various factors of the air pollutants concentrations, this study further assessed the impact of MCO attributed to movement restriction due to COVID-19 pandemic on both spatial and temporal distribution of four major air pollutants across Malaysia using official observations from 65 air quality monitoring stations owned by the government. To further understand the temporal and spatial effects of MCO on the air quality pattern, monitoring data equipped with $\mathrm{PM}_{2.5}, \mathrm{CO}, \mathrm{NO}_{2}$, and $\mathrm{SO}_{2}$ observations were classified into different settings of sub-urban, urban, industrial, rural, and background stations. To evaluate possible associated sources in the variations of major air pollutants concentrations before and during MCO, temporal analyses on daily average of major air pollutant concentrations for all 65 stations across Malaysia during MCOs were studied and compared with daily average concentrations before MCO for each station. The spatial interpolation method was then used to assess the spatial variations of concentrations throughout the MCO phases. Additionally, MODIS-fire data were used to observe biomass-burning activities in Malaysia, and meteorological parameters were used to explain the variations of air pollutants during the study period. This study could lead to a better understanding of the air quality pattern, particularly in Malaysia, spatially and temporally. Such findings could be used as a fundamental and baseline setting for a more holistic policy in managing the air quality post COVID-19 period.

\section{METHODS}

\section{Study Area}

This study focused on the analysis of air pollutant concentrations from 65 official air quality observation stations across the nation that are retrieved from Department of Environment, Malaysia. The air quality observation stations are maintained and supervised by Transwater Sdn Bhd that has been awarded a 15-year concession by the Malaysia government. From all 65 stations, 34 stations located at sub-urban area, 11 stations at urban area, seven stations at industrial area, 12 stations at rural areas, and one station is categorized as a background station as shown in Fig. 1. The stations were also divided into seven regional classifications namely, northern, central, eastern, and southern of Peninsular Malaysia, Sabah, Sarawak, and Labuan. 

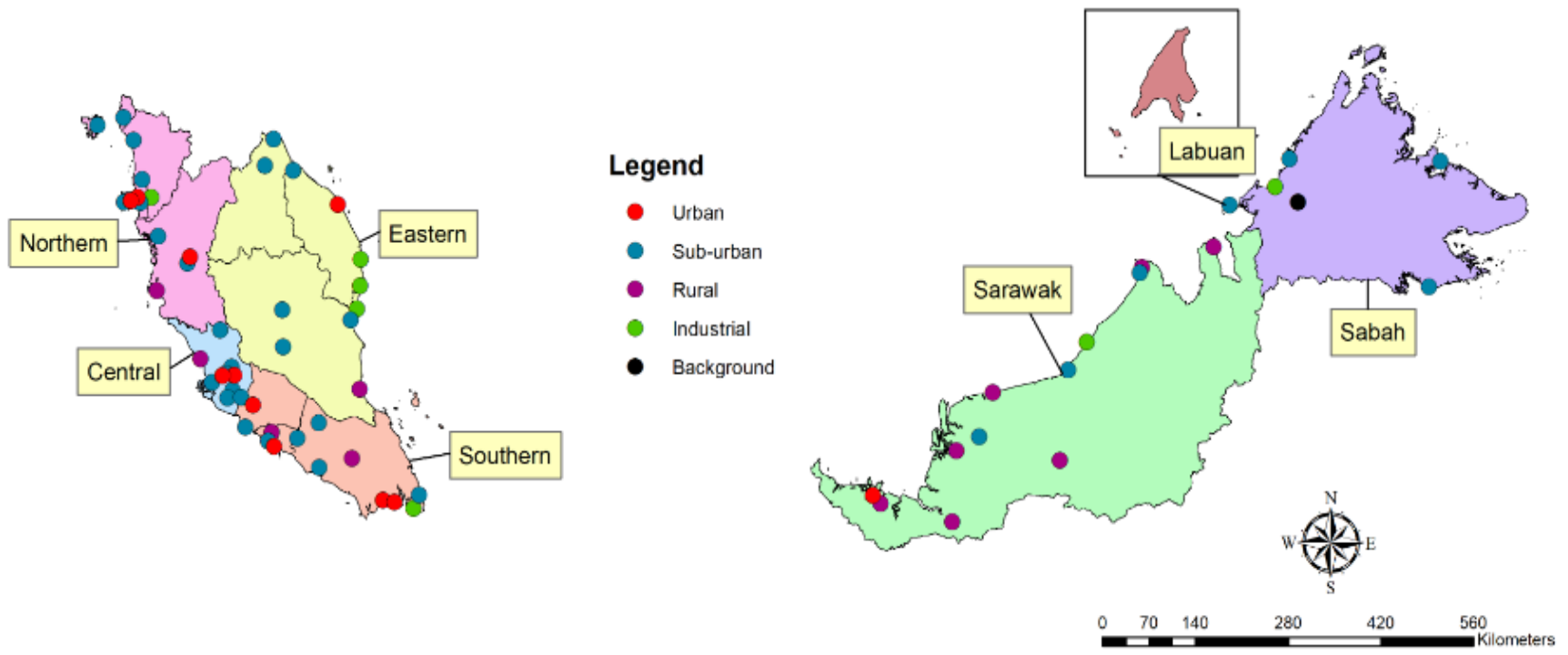

Fig. 1. Geographical distribution of air quality monitoring stations in Malaysia classified based on locality. The regions are identified by name.

\section{Datasets}

$\mathrm{PM}_{2.5}, \mathrm{NO}_{2}, \mathrm{SO}_{2}$, and $\mathrm{CO}$ air quality datasets were obtained over a period of March 4-March 17, 2020 (before MCO) and March 18-May 12, 2020 (during four phases of MCO). $\mathrm{PM}_{2.5}$ data were available for all 65 stations. However, $\mathrm{CO}$ data were only available for sub-urban, urban, and background stations, while $\mathrm{NO}_{2}$ and $\mathrm{SO}_{2}$ data were not available for rural stations. This is due to concessionaire agreements between the Department of Environment (DOE) and Transwater Sdn Bhd that decided to measure only related pollutants based on major economy activities in each setting.

The standard measurement methods were used to quantify the concentrations. $\mathrm{PM}_{2.5}$ concentrations are measured using a Thermo Scientific TEOM 1405-DF, which is a continuous dichotomous ambient air monitoring system with two Filter Dynamics Measurements Systems. It provides three measurements: $\mathrm{PM}_{10}, \mathrm{PM}_{2.5}$, and PM-Coarse, while accounting for volatile and nonvolatile PM fractions with accuracy for mass measurement $\pm 0.75 \%$. $\mathrm{NO}_{2}, \mathrm{SO}_{2}$, and $\mathrm{CO}$ concentrations were measured using Thermo Scientific Model 42i NO$\mathrm{NO}_{2}-\mathrm{NO}_{\mathrm{x}}$ Analyzer, Thermo Scientific Model 43i $\mathrm{SO}_{2}$ Analyzer, and Thermo Scientific Model 48i CO Analyzer, respectively. As part of quality assurance and quality control (QA/QC), all data have gone through pre-processing treatment, including the detection of errors and missing values. The percentage of missing data only encompassed insignificant percentage, which is $<5 \%$ and were omitted from the analysis. Locations of active fire hotspots data during the study period were processed from MODIS Fire and Thermal Anomalies data product with moderate resolution $(\sim 1 \mathrm{~km})$ retrieved from NASA Fire Information for Resource Management portal (https://earthdata.nasa.gov/earth-observ ation-data/near-real-time/firms).

To account for the potential meteorological influence, three meteorological parameters, namely wind speed (WS), relative humidity $(\mathrm{RH})$, and temperature $(\mathrm{T})$ were obtained from Malaysian Meteorological Department (MMD) for 39 stations across the country.

\section{Data Analysis}

Several statistical analyses were conducted to determine the variations of pollutants concentrations and meteorological data and to compare the concentration of all pollutants and meteorological data between pre- and during MCOs. Hourly data were used to calculate the average daily concentration of each pollutant for each station and then the average daily data were divided and classified based on equal 14-day before and during the MCO phases (Table 1). The decrease ratio is calculated as $X_{t} / X_{t-1}$, where $X$ denotes as average concentration of each pollutant and the subscript represents the time periods. Diurnal and weekly variations of each pollutant were also evaluated for each setting.

One-Sample Kolmogorov-Smirnov test was used to assess the normality of the data for each station. Based on Kolmogorov-Smirnov test, data that were not normally distributed were analyzed using non-parametric techniques, while data that were normally distributed were analyzed using parametric techniques. Kruskal-Wallis and Analysis of Variance (ANOVA) tests were used to compare whether there was any statistically significant difference among the average concentration between station categories, and Wilcoxon Signed Rank test and student's t-test were used to compare between time periods both for air pollutants and meteorological data. The interpolation approach, Kriging analysis was used in this study to visualize the spatial distribution of pollutants across MCO phases. Kriging analysis used each of station's average pollutants values according to the designated time periods to interpolate the spatial variations. Calculation and comparison between the Kriging interpolation method with other interpolation methods can be further referred to in Wong et al. (2004). Nonetheless, Spearman's correlation test was used to assess the influence of meteorological data on variations of air pollutant concentrations before and during MCO phases. 
Table 1. Details on time frame used for the study.

\begin{tabular}{|c|c|c|}
\hline Time & Date & Duration \\
\hline Before MCO & March $4^{\text {th }}, 2020-$ March $17^{\text {th }}, 2020$ & 14 days \\
\hline MCO Phase 1 (MCO P1) & March $18^{\text {th }}, 2020-$ March 31 $1^{\text {st }}, 2020$ & 14 days \\
\hline MCO Phase 2 (MCO P2) & April $1^{\text {st }}, 2020-$ April $14^{\text {th }}, 2020$ & 14 days \\
\hline MCO Phase 3 (MCO P3) & April $15^{\text {th }}, 2020-$ April $28^{\text {th }}, 2020$ & 14 days \\
\hline MCO Phase 4 (MCO P4) & April $29^{\text {th }}, 2020-$ May $12^{\text {th }}, 2020$ & 14 days \\
\hline $\begin{array}{l}\text { Note: Conditional Movement Control Order }(C M C O) \\
\text { starts at } 4^{\text {th }} \text { May } 2020\end{array}$ & & \\
\hline
\end{tabular}

\section{RESULTS AND DISCUSSION}

\section{Changes in Daily Movement during COVID-19 Movement Control Order (MCO) in Malaysia}

The Malaysian government implemented comprehensive and strict measures to stop the spread of COVID-19 nationwide (Table S1). These control measures restricted the movement of people hence reduced numbers of vehicles on the roads which in turn may improve air quality across the country (Dutheil et al., 2020; Li and Tartarini, 2020). This is consistent with a report from Google which exhibits that mobility levels in Malaysia decline immediately after the enforcement of $\mathrm{MCO}$ except for residential category (Fig. 2). Google used data collected from users who allowed Google to access their location and analyzed the changes by comparing it with baseline value. Baseline value is the median value for the corresponding day of the week, during the five week period 3 Jan-6 Feb 2020 (Google LLC, 2020). The movement in residential increase $23 \%$ from the baseline value after the implementation of MCO. This is due to the policy which restricted the movement to a $10 \mathrm{~km}$ radius from homes. Movement trend in other place reduced between 14 to $56 \%$ immediately on the first day of MCO. The movement trends for workplace, grocery and pharmacy, and transit station started to increase slowly after the implementation of CMCO where more businesses are allowed to re-open (Bernama, 2020a).

\section{Variations of Meteorology Parameters}

The summary of meteorological data is shown in Table 2.
During the study period, Malaysia has inter-monsoon season between March and April and early stage of Southwest (SW) monsoon in early May. Generally, the average of the WS, $\mathrm{RH}$, and $\mathrm{T}$ were in the range of 7.30 to $10.72 \mathrm{~m} \mathrm{~s}^{-1}, 71.53$ to $84.42 \%$, and 26.67 to $30.56^{\circ} \mathrm{C}$, respectively, before MCO. Nonetheless, the average of the WS shows a slightly decreasing trend ( 6.55 to $10.10 \mathrm{~m} \mathrm{~s}^{-1}$ ) at the end of MCO, which might be attributed to seasonal change (Fig. S1). The RH indicates a slightly higher reading during MCO when compared to before MCO with the range of 75.20 to $86.43 \%$. The temperature during $\mathrm{MCO}$ phases shows consistent readings when compared with before $\mathrm{MCO}$ with average value of $28.65^{\circ} \mathrm{C}$. Lower $\mathrm{WS}$ and higher $\mathrm{RH}$ usually lead to higher pollutants value hence higher concentrations should be expected during MCO (Navinya et al., 2020).

Furthermore, correlation analysis showed that the WS has a negative significant relationship $(\mathrm{p}<0.05)$ with $\mathrm{CO}$ and $\mathrm{NO}_{2}$ before $\mathrm{MCO}$, suggesting that these two pollutant values during this period could be higher (Table 2). However, $\mathrm{NO}_{2}$ was also strikingly influenced by temperature $(\mathrm{p}<0.05)$ and $\mathrm{CO}$ was significantly influenced by $\mathrm{RH}(\mathrm{p}<0.05) . \mathrm{PM}_{2.5}$ was not significantly influenced by any meteorological parameters before MCO. During MCO, $\mathrm{PM}_{2.5}(\mathrm{r}=-0.552)$ and $\mathrm{NO}_{2}(\mathrm{r}=-0.299)$ has a significant negative relationship with RH ( $p<0.05)$. Negative correlation is due to high humidity which commonly related to raining events, and this reduces the number of pollutants in the atmosphere (Azmi et al., 2010).

Further investigation using pairwise comparison based on student t-test with Bonferroni correction were exhibits the

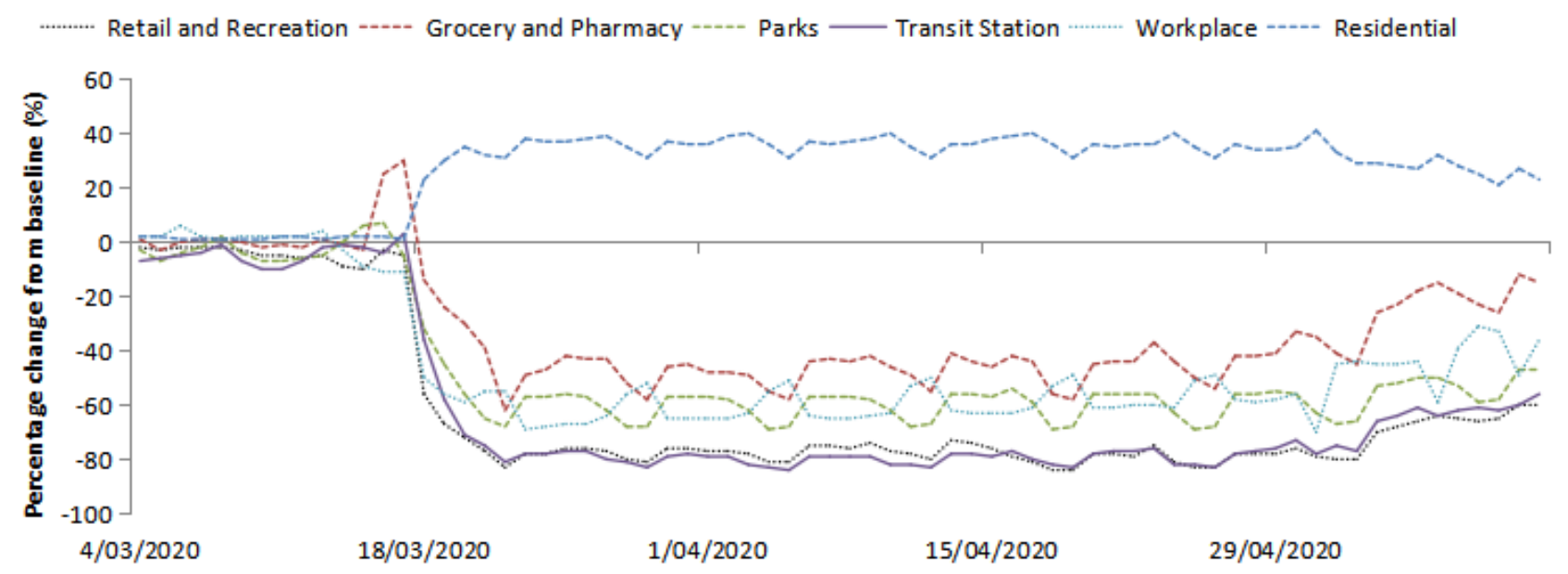

Fig. 2. Mobility trend due to COVID-19 (Google LLC, 2020). 
Table 2. Summary of meteorological parameters and relationship with air pollutants.

\begin{tabular}{llllllllll}
\hline \multirow{2}{*}{ Variables } & \multirow{2}{*}{ Time } & \multirow{2}{*}{ Min } & \multirow{2}{*}{ Max } & \multirow{2}{*}{ Median } & \multirow{2}{*}{$\mathrm{S} . \mathrm{D}$} & \multicolumn{4}{c}{$\mathrm{r}$} \\
\cline { 7 - 10 } & & & & $\mathrm{PM}_{2.5}$ & $\mathrm{CO}$ & $\mathrm{NO}_{2}$ & $\mathrm{SO}_{2}$ \\
\hline Wind Speed & Before MCO & 7.3 & 10.72 & 8.55 & 0.84 & -0.389 & $-.589^{*}$ & $-.719^{*}$ & -0.169 \\
$\left(\mathrm{~m} \mathrm{~s}^{-1}\right)$ & During MCO & 6.55 & 10.1 & 8.23 & 0.76 & 0.497 & 0.117 & 0.045 & -0.25 \\
Relative Humidity & Before MCO & 71.53 & 84.42 & 78.86 & 3.63 & 0.204 & $.816^{*}$ & 0.646 & -0.351 \\
$(\%)$ & During MCO & 75.2 & 86.43 & 80.99 & 2.87 & $-.552^{*}$ & -0.063 & $-.299^{*}$ & -0.26 \\
Temperature & Before MCO & 26.67 & 30.56 & 28.85 & 1.2 & 0.085 & -0.484 & $-.686^{*}$ & 0.018 \\
$\left({ }^{\circ} \mathrm{C}\right)$ & During MCO & 26.67 & 30 & 28.6 & 0.99 & 0.159 & -0.045 & 0.154 & 0.447 \\
\hline
\end{tabular}

*relationship is significant at $p<0.05$.

daily average of WS, T, and $\mathrm{RH}$ during $\mathrm{MCO}$ were not significantly different when compared with daily average recorded before MCO. This suggests that pollution decline during MCO might not contributed by the changes in meteorology alone but can likely be attributed to changes in daily and economic activities due to COVID-19 containment measures (Li and Tartarini, 2020; Navinya et al., 2020).

\section{Temporal and Spatial Variations of Air Pollutants}

Table 3 shows the ambient air quality standard from the World Health Organization (WHO) and the Department of Environment (DOE) Malaysia. Generally, WHO has more stringent standards $\left(\mathrm{PM}_{2.5}: 25 \mu \mathrm{g} \mathrm{m}^{-3}, \mathrm{NO}_{2}: 21.256 \mathrm{ppm}\right.$, and $\mathrm{SO}_{2}$ : $\left.7.633 \mathrm{ppm}\right)$ compared to $\mathrm{DOE}$ Malaysia $\left(\mathrm{PM}_{2.5}\right.$ : $35 \mu \mathrm{g} \mathrm{m}^{-3}, \mathrm{NO}_{2}: 37.198 \mathrm{ppm}$, and $\left.\mathrm{SO}_{2}: 30.534 \mathrm{ppm}\right)$. Fig. 3 shows the temporal variations in the average of $\mathrm{PM}_{2.5}, \mathrm{CO}$, $\mathrm{NO}_{2}$, and $\mathrm{SO}_{2}$ concentrations from March 4 until May 12, 2020, for the five station categories across Malaysia. Generally, daily average of $\mathrm{PM}_{2.5}$ concentrations range from 2.06 to $41.28 \mu \mathrm{g} \mathrm{m}^{-3}, 3.98$ to $37.5 \mu \mathrm{g} \mathrm{m}^{-3}, 4.16$ to $39.01 \mu \mathrm{g} \mathrm{m}^{-3}, 3.21$ to $86.01 \mu \mathrm{g} \mathrm{m}^{-3}$, and 7.79 to $12.35 \mu \mathrm{g} \mathrm{m}^{-3}$ for sub-urban, urban, industrial, rural, and background stations, respectively. Considering WHO (WHO, 2005) and DOE Malaysia air quality guidelines, maximum values of all settings exceed the threshold values of $25 \mathrm{\mu g} \mathrm{m}^{-3}$ and $35 \mu \mathrm{g} \mathrm{m}^{-3}$ (24-hour mean), respectively, except for background station. The daily average $\mathrm{CO}$ concentrations range from 0.39 to $0.59 \mathrm{ppm}, 0.39$ to $0.70 \mathrm{ppm}$, and 0.53 to $0.84 \mathrm{ppm}$ for sub-urban, urban, and background station. Also, the daily average $\mathrm{NO}_{2}$ concentrations range from 0.0021 to $0.0056 \mathrm{ppm}, 0.0025$ to $0.011 \mathrm{ppm}, 0.0013$ to $0.0036 \mathrm{ppm}$, and 0.0011 to $0.0052 \mathrm{ppm}$ for sub-urban, urban, industrial, and background stations. Both $\mathrm{CO}$ and $\mathrm{NO}_{2}$ concentrations in all settings meet the standards. $\mathrm{SO}_{2}$ concentrations at all settings are very low, thus also did not exceed the standards.

Overall, significant decreases $(p<0.05)$ in concentrations of $\mathrm{PM}_{2.5}, \mathrm{NO}_{2}$, and $\mathrm{CO}$ were observed in sub-urban and urban stations throughout the MCO phases despite the impact of biomass burning emissions in Malaysia during this time (Table 4 and Fig. 3). However, there were no significant reductions in $\mathrm{SO}_{2}$ readings for all stations categories during MCO when compared with before MCO. The highest reduction in $\mathrm{PM}_{2.5}, \mathrm{NO}_{2}$, and $\mathrm{CO}$ concentration was observed from the urban stations with average daily concentration of $17.49 \mu \mathrm{g} \mathrm{m}^{-3}, 0.0087 \mathrm{ppm}$, and $0.6388 \mathrm{ppm}$ before MCO to $13.44 \mu \mathrm{g} \mathrm{m}^{-3}, 0.0040 \mathrm{ppm}$, and $0.499 \mathrm{ppm}$ during MCOs, indicating $23.1 \%, 54.0 \%$, and $21.7 \%$ total reduction. A significant reduction in sub-urban, urban, and industrial stations for $\mathrm{PM}_{2.5}$ concentrations can be observed 4 weeks after MCO was enforced (MCO P3) compared to before MCO (Fig. 4), while the reduction of $\mathrm{CO}$ concentration can be observed as early as MCO P1, clearly indicating the effect of MCO $(p<0.05)$ (Fig. 4). $\mathrm{NO}_{2}$ concentrations indicate a reduction starting from MCO P1 until MCO P3, followed by a slight increase during MCO P4 due to relaxation of some measures during CMCO (Fig. 4). SO concentrations in all settings show no significant changes when compared between before $\mathrm{MCO}$ with during $\mathrm{MCO}$, which is perhaps due to low readings.

Nevertheless, a significant increase in $\mathrm{PM}_{2.5}$ concentrations from pre-MCO throughout $\mathrm{MCO}$ phases with a relative change of approximately $+20.38 \%$, in background station, which is located at Keningau, Sabah, was observed during the study period (Table 4). However, $\mathrm{NO}_{2}$ concentrations showed a significant reduction with a relative change of $-52.6 \%$ when compared before $\mathrm{MCO}$ with during $\mathrm{MCO}$. This suggests the Keningau station is affected by local vehicular emission sources as a study shows the pollution over background station is attributed to the transport sector, but the increment of $\mathrm{PM}_{2.5}$ concentration might be contributed by local and midrange transport of biomass-burning pollution in neighboring areas (Latif et al., 2014; Ee-Ling et al., 2015).

Table 3. Ambient air quality standards from World Health Organization (WHO) and the Department of Environment Malaysia (DOE).

\begin{tabular}{|c|c|c|c|c|}
\hline \multirow{2}{*}{ Pollutants } & \multicolumn{2}{|c|}{ WHO } & \multicolumn{2}{|c|}{ DOE Malaysia } \\
\hline & Time Range & Value $\left(\mu \mathrm{g} \mathrm{m}^{-3}\right)$ & Time range & Value $\left(\mu \mathrm{g} \mathrm{m}^{-3}\right)$ \\
\hline $\mathrm{PM}_{2.5}$ & $24 \mathrm{~h}$ & 25 & $24 \mathrm{~h}$ & 35 \\
\hline $\mathrm{CO}$ & - & - & $8 \mathrm{hr}$ & $10(8.729)$ \\
\hline $\mathrm{NO}_{2}$ & 1 year & $40(21.256)$ & $24 \mathrm{hr}$ & $70(37.198)$ \\
\hline $\mathrm{SO}_{2}$ & $24 \mathrm{hr}$ & $20(7.633)$ & $24 \mathrm{hr}$ & $80(30.534)$ \\
\hline
\end{tabular}

Note: Concentration in ppm is shown in bracket. 

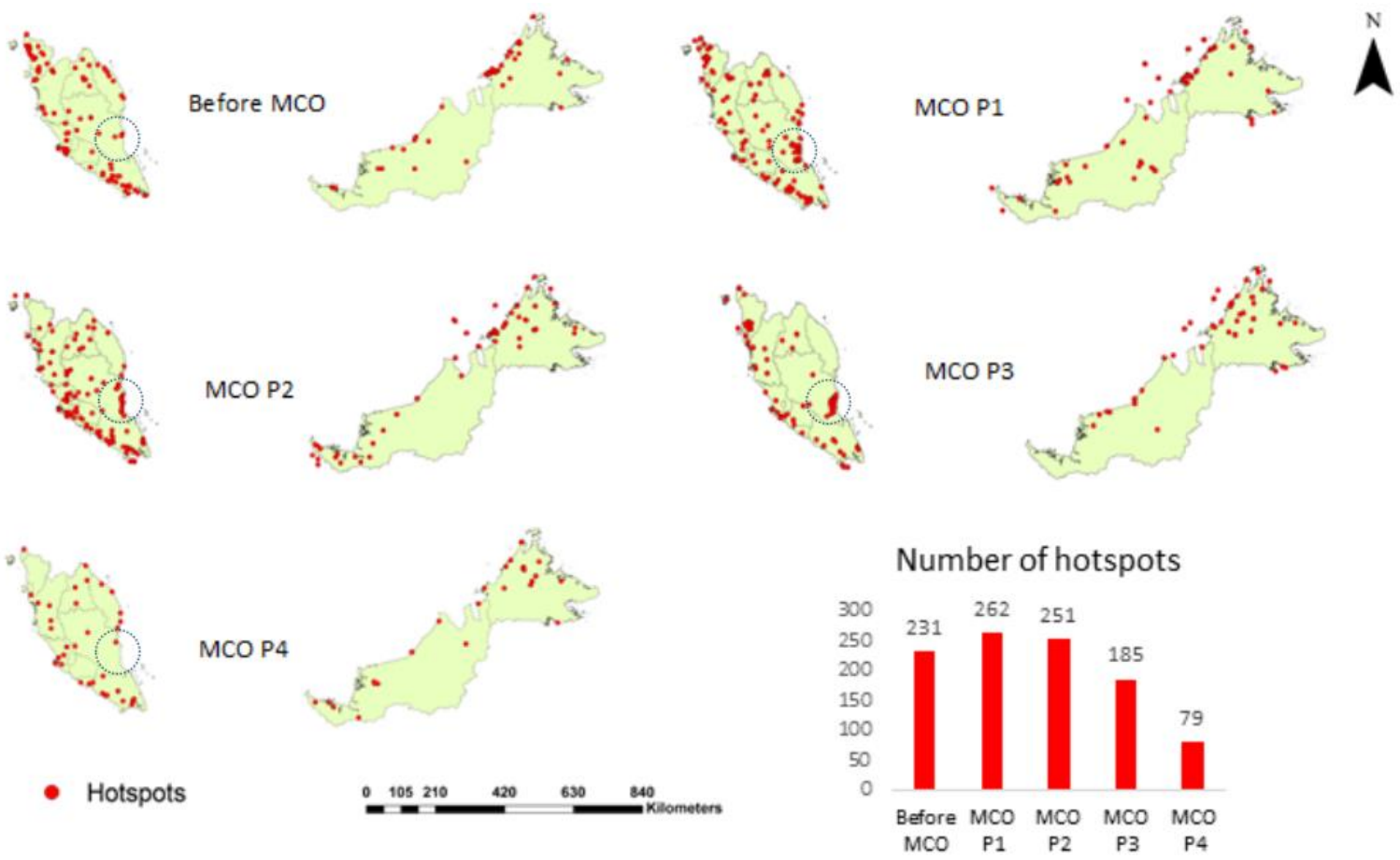

Fig. 3. Hotspots distribution across Malaysia. Blue circle indicates Rompin area.

Table 4. Average concentration, variations before and during MCOs and relative change (\%) of: $\mathrm{PM}_{2.5}, \mathrm{CO} \mathrm{NO}_{2}$, and $\mathrm{SO}_{2}$ according to stations categories.

\begin{tabular}{|c|c|c|c|c|c|c|c|c|c|}
\hline \multirow[b]{2}{*}{ Categories } & \multirow[b]{2}{*}{ Time } & \multicolumn{8}{|c|}{ Average concentrations } \\
\hline & & $\begin{array}{l}\mathrm{PM}_{2.5} \\
\left(\mu \mathrm{g} \mathrm{m}^{-3}\right)\end{array}$ & $\%$ & $\begin{array}{l}\mathrm{CO} \\
(\mathrm{ppm})\end{array}$ & $\%$ & $\begin{array}{l}\mathrm{NO}_{2} \\
\text { (ppm) }\end{array}$ & $\%$ & $\begin{array}{l}\mathrm{SO}_{2} \\
(\mathrm{ppm})\end{array}$ & $\%$ \\
\hline \multirow[t]{2}{*}{ Sub-urban } & Before $\mathrm{MCO}$ & 16.55 & $-22.1^{+}$ & 0.5482 & $-15.58^{+}$ & 0.0048 & $-41.6^{+}$ & 0.00085 & -5.88 \\
\hline & During $\mathrm{MCO}$ & 12.88 & & 0.4628 & & 0.0028 & & 0.0008 & \\
\hline \multirow[t]{2}{*}{ Urban } & Before $\mathrm{MCO}$ & 17.49 & $-23.1^{+}$ & 0.6388 & $-21.74^{+}$ & 0.0087 & $-54.0^{+}$ & 0.0009 & 0 \\
\hline & During $\mathrm{MCO}$ & 13.44 & & 0.4999 & & 0.004 & & 0.0009 & \\
\hline \multirow[t]{2}{*}{ Industrial } & Before $\mathrm{MCO}$ & 13.11 & $-21.1^{+}$ & NA & NA & 0.0025 & $-20.0^{+}$ & 0.0009 & -11.11 \\
\hline & During $\mathrm{MCO}$ & 10.35 & & NA & & 0.002 & & 0.0008 & \\
\hline \multirow[t]{2}{*}{ Rural } & Before $\mathrm{MCO}$ & 10.73 & -9.4 & NA & NA & NA & NA & NA & NA \\
\hline & During $\mathrm{MCO}$ & 9.72 & & NA & & NA & & NA & \\
\hline \multirow[t]{2}{*}{ Background } & Before $\mathrm{MCO}$ & 7.86 & $20.3^{+}$ & 0.7144 & 7.56 & 0.0038 & $-52.6^{+}$ & 0.0007 & 14.28 \\
\hline & During $\mathrm{MCO}$ & 9.46 & & 0.6604 & & 0.0018 & & 0.0008 & \\
\hline
\end{tabular}

${ }^{+}$indicate average concentration before MCO vs. average concentration during MCOs significant at $p<0.05$; NA: not available.

Figs. 5(a)-5(d) shows spatial variations of 4 major pollutants before MCO and throughout four MCO phases across the country. $\mathrm{PM}_{2.5}$ shows highest variations in northern and central part of Peninsular Malaysia, which is associated with high emissions from factories, power plants, vehicles, and local biomass burning before the implementation of MCO (Fig. 5(a)). The concentrations of $\mathrm{PM}_{2.5}$ reduced considerably during MCO P2 and reached average less than $15 \mu \mathrm{g} \mathrm{m}^{-3}$ during MCO P4 across the country. Nonetheless, $\mathrm{CO}$ and $\mathrm{NO}_{2}$ show high concentrations in central regions before MCO because the area is highly urbanized (Figs. 5(b) and 5(c)). A sudden decline in $\mathrm{CO}$ and $\mathrm{NO}_{2}$ concentrations was observed immediately when MCO started, where average concentrations reduced from $0.8-1.0 \mathrm{ppm}$ before $\mathrm{MCO}$ to
0.2-0.4 ppm during $\mathrm{MCO}$ for $\mathrm{CO}$ and from 0.01-0.012 ppm before MCO to $0.006-0.008$ ppm during $\mathrm{MCO}$ for $\mathrm{NO}_{2}$. A slight increase was observed in $\mathrm{NO}_{2}$ concentrations during MCO P4 compared to other MCO phases due to the implementation of CMCO, where some factories and economic activities were allowed to re-open, especially in the central part of Peninsular. As known, the main sources of $\mathrm{NO}_{2}$ are from motor vehicles and industrial emissions (Awang et al., 2000; Afroz et al., 2003; Navinya et al., 2020). $\mathrm{SO}_{2}$ concentrations showed a consistent pattern when compared between before MCO with during MCO. As known, main anthropogenic sources of $\mathrm{SO}_{2}$ are from cars and burning fossil fuels for electricity generation. This explained why high $\mathrm{SO}_{2}$ readings can be observed in highly 

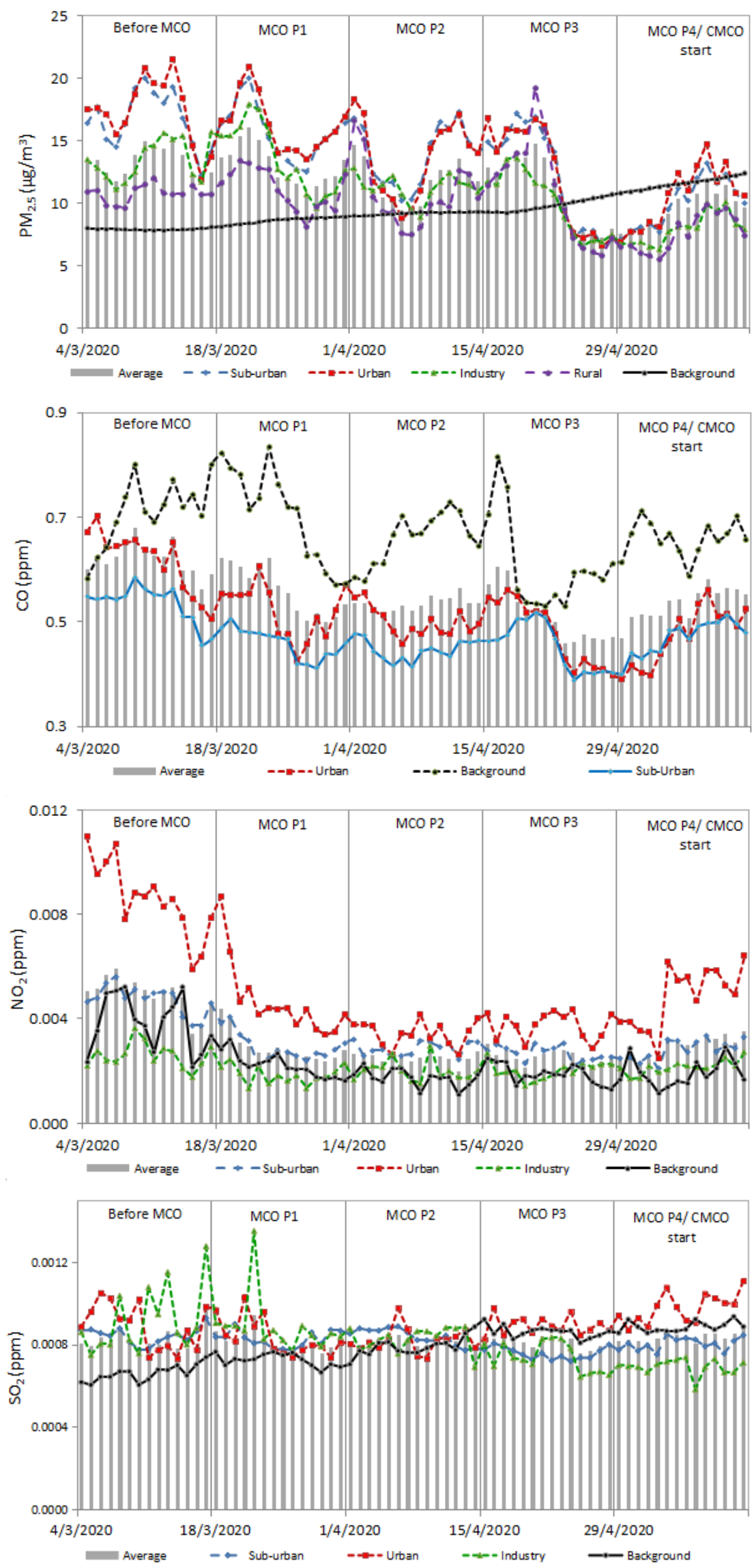

Fig. 4. Average concentrations of $\mathrm{PM}_{2.5}, \mathrm{CO}, \mathrm{NO}_{2}$ and $\mathrm{SO}_{2}$ according to stations settings. 
(a)

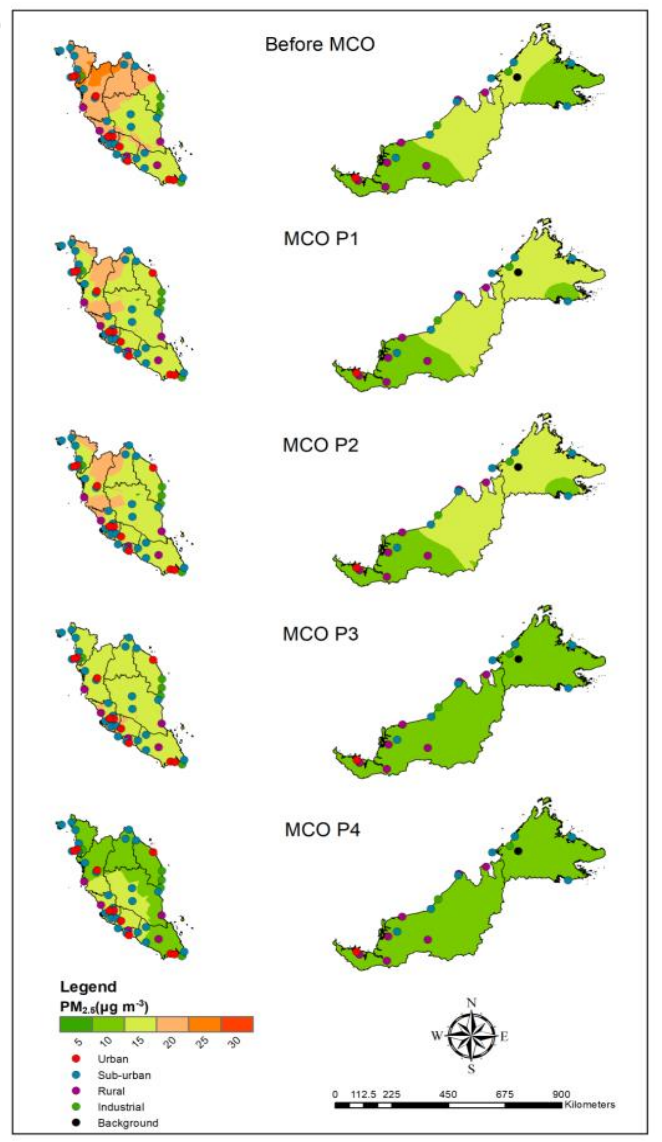

(c)

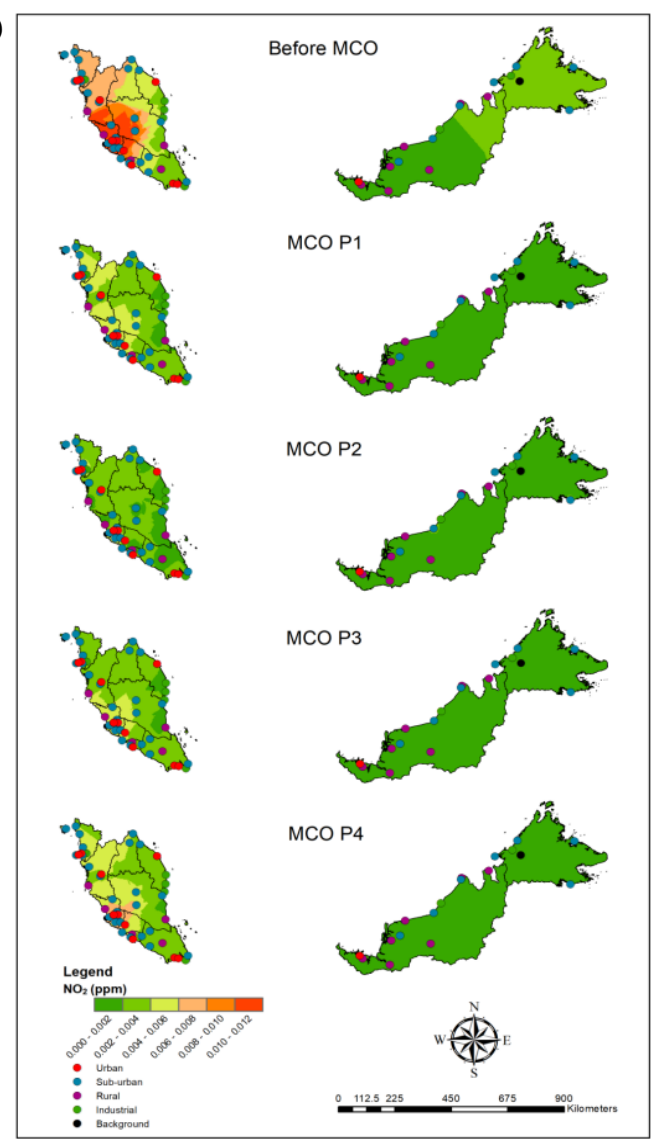

(b)

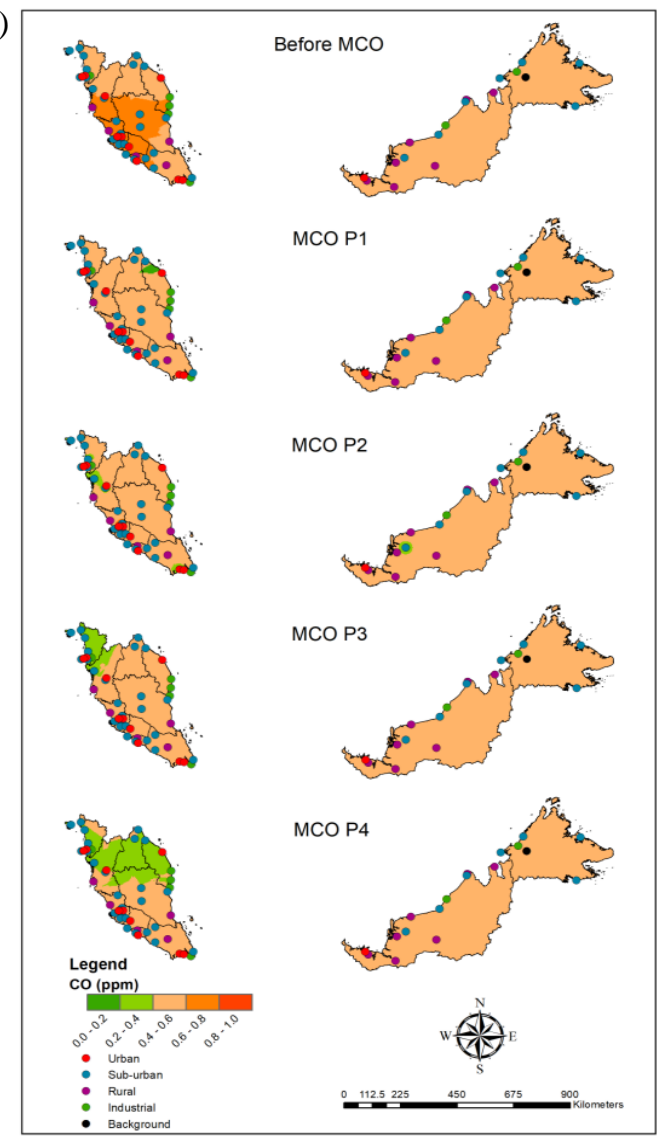

(d)

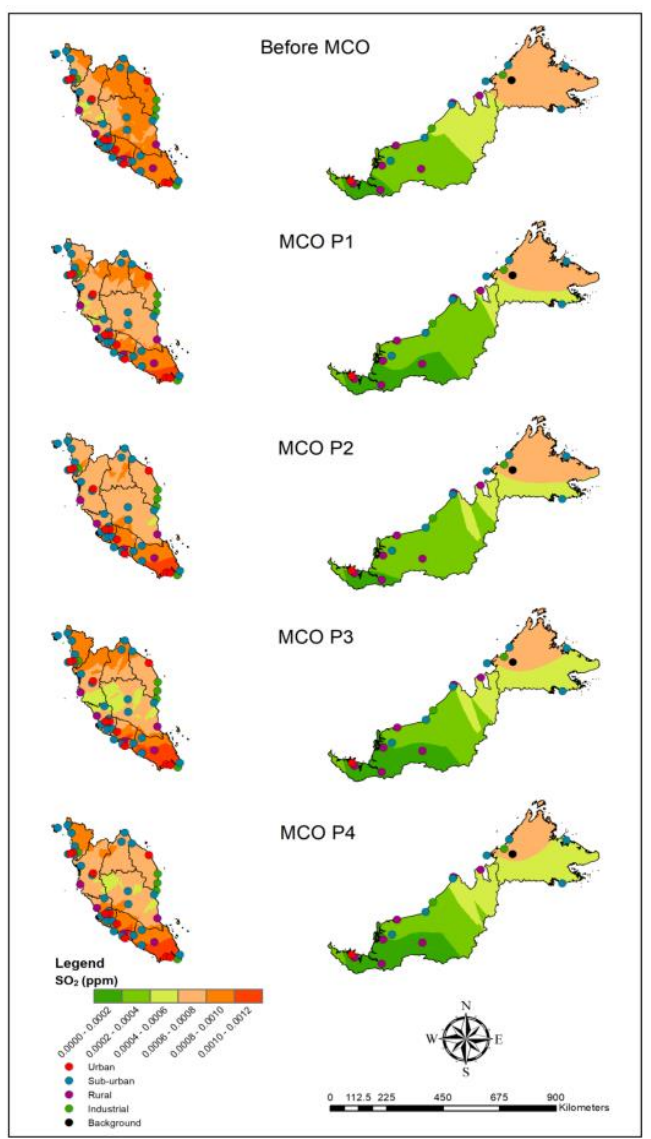

Fig. 5. Spatial distribution of (a) $\mathrm{PM}_{2.5}$, (b) $\mathrm{CO}$, (c) $\mathrm{NO}_{2}$ and (d) $\mathrm{SO}_{2}$ concentration during study periods. 
populated regions; north, central, and south part of Peninsular. Nonetheless, higher $\mathrm{CO}(0.8-1.0 \mathrm{ppm})$ and $\mathrm{SO}_{2}$ values $(0.001-0.0012 \mathrm{ppm})$ were recorded in East part of Peninsular before MCO, where there are huge oil gas processing and utility plants in the region. However, the $\mathrm{CO}$ and $\mathrm{SO}_{2}$ readings decreased immediately to $0.4-0.6 \mathrm{ppm}$ and 0.0002-0.0004 ppm, respectively, during MCO P1 due to minimum production activities. The readings started to increase again during MCO P4 when the implementation of CMCO allowed most of the industries to re-open as usual. Most regions showed a reduction of $\mathrm{PM}_{2.5}$ concentration during MCO P4 compared to MCO P3, even most of the activities were re-started during $\mathrm{MCO} \mathrm{P} 4$ due to $\mathrm{CMCO}$, while other concentrations showed a slight increase during MCO P4 compared to MCO P3. This is perhaps due to the reduction in fire emissions as observed from MODIS data product (Fig. 3). Fire activities during MCO P4 decreased remarkably to 78 counts from 231,262, 251, and 185 counts during pre-, MCO P1, MCO P2, and MCO P3, respectively. This suggests that $\mathrm{PM}_{2.5}$ concentration in this region may influenced by biomass-burning activities.

Fig. 6 shows the diurnal variations of $\mathrm{PM}_{2.5}, \mathrm{CO}, \mathrm{NO}_{2}$, and $\mathrm{SO}_{2}$ for all settings for pre- and during MCO. On national scale, $\mathrm{PM}_{2.5}$ shows less obvious diurnal patterns throughout the day. This may be due low 24-h average concentration where the daily means exhibit values lower than $30 \mu \mathrm{g} \mathrm{m}^{-3}$ in all settings (Chen et al., 2020). The peaks for $\mathrm{NO}_{2}, \mathrm{CO}$, and $\mathrm{SO}_{2}$ concentrations were distributed in the morning starting at 8 am which was correlated to morning traffic rush hours (Afroz et al., 2003; Azmi et al., 2010). High concentrations of $\mathrm{NO}_{2}, \mathrm{CO}$, and $\mathrm{SO}_{2}$ were also observed in the late evening is generally due to meteorological influence and atmospheric stability (Awang et al., 2000). Nonetheless, highest concentrations of $\mathrm{PM}_{2.5}, \mathrm{NO}_{2}$, and $\mathrm{CO}$ were found in urban stations which it is highly possible that these concentrations are from vehicular emissions (Mohd Nadzir et al., 2020; Suhaimi et al., 2020). Although there was change in daily activities during MCO, similar diurnal patterns were observed; however, significant lower readings were observed in all settings.

For weekly variations, all pollutants show less variation throughout the week during MCO when compared with preMCO (Fig. 7). The lowest concentrations for $\mathrm{PM}_{2.5}$ before MCO appear in Mondays and gradually increase until Friday and reduced again during the weekend. Urban stations exhibit highest concentrations of $\mathrm{PM}_{2.5}$ followed by sub-urban stations. Weekly variations of $\mathrm{CO}$ and $\mathrm{NO}_{2}$ were similar with $\mathrm{PM}_{2.5}$ especially in urban and sub-urban stations suggesting the concentrations of these pollutants may come from similar sources. There is no obvious weekly pattern for $\mathrm{SO}_{2}$ before MCO although highest concentrations were appear on Tuesday.

\section{Site-scale Analysis of Air Pollutants}

The average of $\mathrm{PM}_{2.5}, \mathrm{CO}, \mathrm{NO}_{2}$, and $\mathrm{SO}_{2}$ concentration in each region and setting were further evaluated to determine its associated sources and the roles of MCO in the variations of pollutant concentrations. Table 5 gives the decrease ratio of $\mathrm{PM}_{2.5}, \mathrm{CO}, \mathrm{SO}_{2}$, and $\mathrm{NO}_{2}$ before $\mathrm{MCO}$ and during $\mathrm{MCO}$ for selected sub-urban, urban, industrial and rural stations (other stations can be found in Tables S2-S5). $\mathrm{PM}_{2.5}, \mathrm{CO}, \mathrm{NO}_{2}$, and $\mathrm{SO}_{2}$ concentration reduction ranged from $9.2-20.5 \%$,
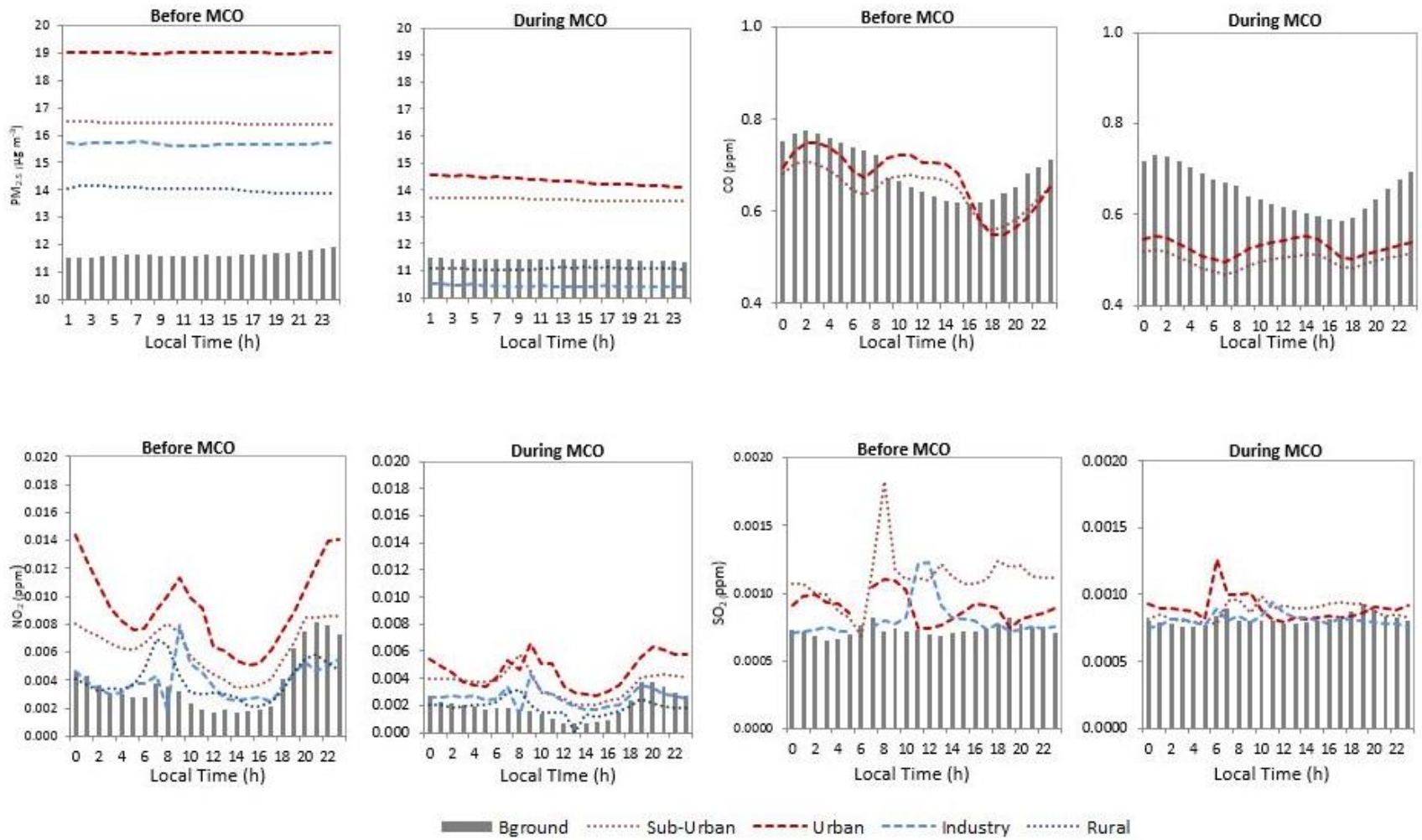

Fig. 6. Diurnal trends of $\mathrm{PM}_{2.5}, \mathrm{CO}, \mathrm{NO}_{2}$, and $\mathrm{SO}_{2}$ according to stations settings during study periods. 

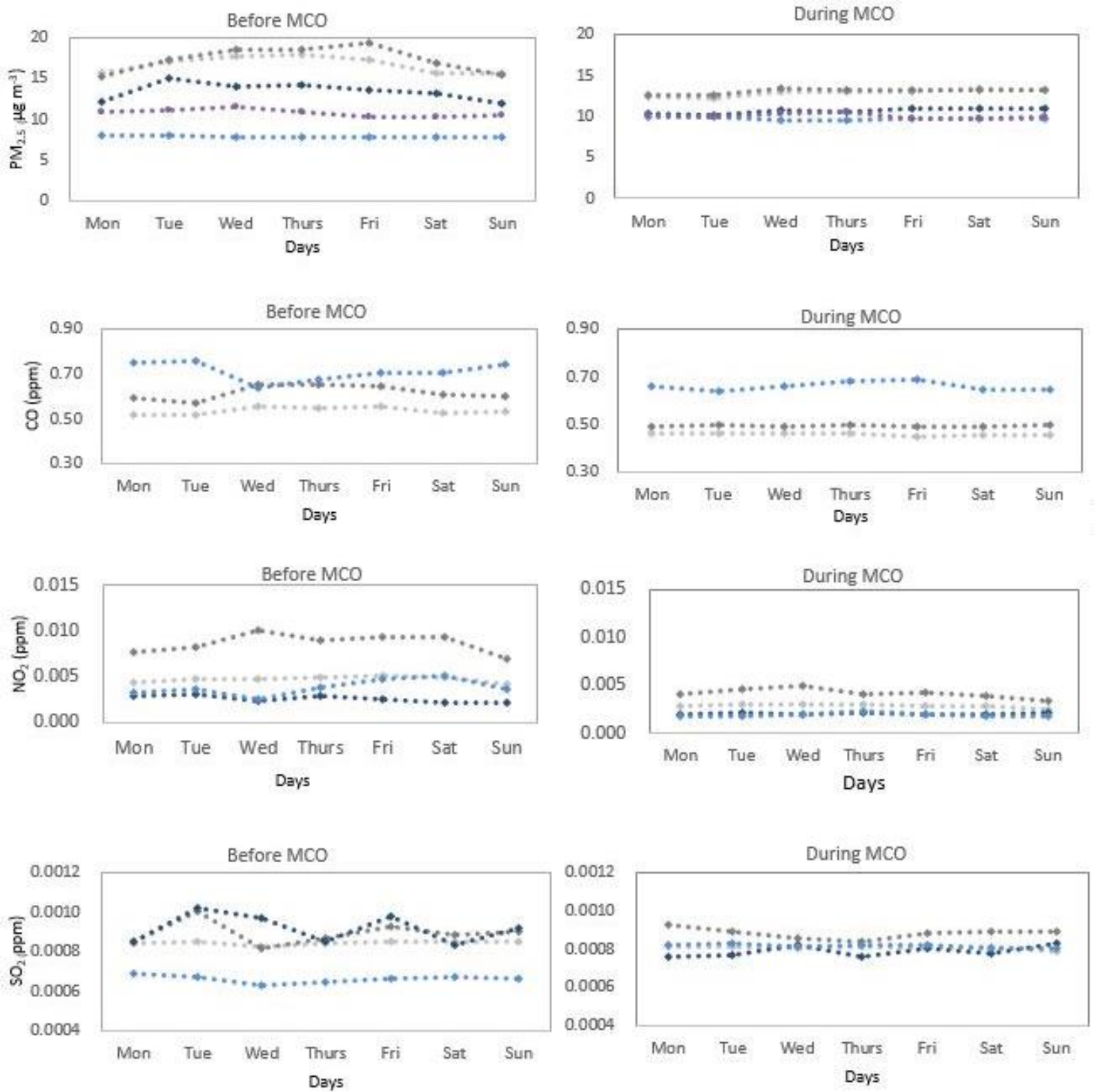

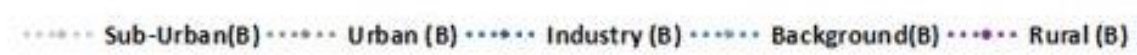

Fig. 7. Weekly trends of $\mathrm{PM}_{2.5}, \mathrm{CO}, \mathrm{NO}_{2}$, and $\mathrm{SO}_{2}$ according to stations settings during study periods.

$1.0-53.4 \%, 4.0-68.2 \%$, and $2.66-52.7 \%$, respectively, during MCO compared with before MCO in sub-urban stations. More than $20 \%$ declined has been observed during MCO over 18,15 , and 13 stations out of 34 sub-urban stations for $\mathrm{PM}_{2.5}, \mathrm{CO}$, and $\mathrm{SO}_{2}$, respectively. Moreover, 32 of 34 suburbans stations showed more than $20 \%$ decline in $\mathrm{NO}_{2}$ concentrations. This agrees with findings from Filonchyk et al. (2020), Navinya et al. (2020), and Venter et al. (2020), who reported that $\mathrm{NO}_{2}$ reduction in East China, India and Europe was more than 20\%. Stations located in Northern Peninsular Malaysia showed a significant reduction $(p<$ 0.05 ) of all pollutants, except for $\mathrm{SO}_{2}$ during $\mathrm{MCO}$ with a total relative change ranging -18 to $-53 \%,-3.2$ to $-27.6 \%$, and -30.2 to $-55.4 \%$ for $\mathrm{PM}_{2.5}, \mathrm{CO}$, and $\mathrm{NO}_{2}$ concentrations, respectively. The highest net reduction of $\mathrm{PM}_{2.5}$ was found in Taiping $(65.5 \%)$ in Perak, followed by Alor Setar $(-61.8 \%)$ and Sungai Petani $(-58.21 \%)$ in Kedah. This is believed to be influenced by the closure of major industrial sectors located less than $3 \mathrm{~km}$ from the stations (Ismail et al., 2017). This is supported by the significant huge reduction of $\mathrm{CO}$ (7.35 to $36.13 \%$ ) and $\mathrm{NO}_{2}$ concentrations (35.43 to $53.43 \%$ ) in this region. Nine and eight out of twelve stations located in the central and south regions show a significant reduction ( $p$ $<0.05)$ in average $\mathrm{PM}_{2.5}$ and $\mathrm{CO}$ concentrations, respectively, during MCOs compared to before $\mathrm{MCO}$ with a relative change ranging in $-23 \%$ to $-47 \%$ for $\mathrm{PM}_{2.5}$, and 12 to $53 \%$ for $\mathrm{CO}$, slightly lower when compared with stations located in the north region, suggesting that the $\mathrm{PM}_{2.5}$ and $\mathrm{CO}$ concentrations 
in the central and southern regions may also be influenced by local and regional biomass burning during the study period, thus effects of other anthropogenic sources to $\mathrm{PM}_{2.5}$ and $\mathrm{CO}$ concentrations were lower (Fig. 3). Nonetheless, the reduction of $\mathrm{NO}_{2}$ was significant in all stations located in the central and south Peninsular, suggesting the impact of movement restriction due to COVID-19 reduction of numbers of vehicles and to the $\mathrm{NO}_{2}$ concentrations (Filonchyk et al., 2020; Şahin, 2020).

Stations located in the East region showed a total significant relative change of $\mathrm{PM}_{2.5}$ concentrations $(p<0.05)$ ranging from $-27 \%$ to $-48 \%$, except for Kota Bharu in Kelantan and Besut in Terengganu stations, which show an insignificant reduction throughout the MCOs when compared with before MCO. The insignificant results may be influenced by the sea breeze circulation since both stations are located in the adjacent of the coastal area (Tahir et al., 2013). However, the implementation of MCO which caused the restriction to most of the daily and economic activities does affect the $\mathrm{NO}_{2}$ and $\mathrm{SO}_{2}$ concentrations in this region. $\mathrm{NO}_{2}$ and $\mathrm{SO}_{2}$ concentrations were reduced up to $58 \%$ and $34 \%$, respectively during MCO when compared to before MCO. Furthermore, most of the stations located in Sabah, Sarawak, and Federal Territory of Labuan showing high variations across MCO phases thus also show no change in all pollutant concentrations except $\mathrm{NO}_{2}$ during $\mathrm{MCO}$ phases when compared to before MCO concentrations.

Table 5 also tabulates the reduction ration (\%) of $\mathrm{PM}_{2.5}$, $\mathrm{CO}, \mathrm{NO}_{2}$, and $\mathrm{SO}_{2}$ according to location of urban settings and locality. The main sources of suspended PM in urban background were reported as motor vehicles, industries, and street dust (Amil et al., 2016; Latif et al., 2018; Mohtar et al., 2018), thus average concentration of $\mathrm{PM}_{2.5}, \mathrm{NO}_{2}$, and $\mathrm{CO}$ in stations located at this setting is expected to show reduction during MCO. Overall, all stations (100\%) show significant reduction in $\mathrm{NO}_{2}$ concentrations, while $63 \%$ stations indicated significant declines in $\mathrm{PM}_{2.5}$ and $\mathrm{CO}$ concentrations $(p<0.05)$ between daily average during preMCO with daily average during all MCOs. The relative change ranges from -11.74 to $-46.43 \%$., -6.56 to $-31.25 \%$, and -1.66 to $-65.56 \%$ for $\mathrm{PM}_{2.5}, \mathrm{CO}$, and $\mathrm{NO}_{2}$ concentrations, respectively. There were only two stations (out of 11), showing significant reduction $(\mathrm{p}<0.05)$ in $\mathrm{SO}_{2}$ concentrations for this setting. Highest significant reduction (relative change before MCO vs. during MCO: between -27.0 to $-46.43 \%$; $p$ $<0.05)$ of $\mathrm{PM}_{2.5}$ distributions was found in northern division of Peninsular Malaysia. These stations are located in a densely populated area and within close proximity to the industrial areas, thus the significant reductions were believed to be influenced by the closure of industries, businesses, and restrictions in daily activities due to the enforcement of MCO (Ismail et al., 2017). All stations located in central region show striking reduction $(p<0.05)$ in $\mathrm{PM}_{2.5}$ concentrations during MCO with relative change of $-32.06 \%$ and $-18.45 \%$ for Cheras in Kuala Lumpur and Shah Alam, in Selangor stations, respectively. These two stations are well known with higher populated area and an unprecedented reduction in economic activities during MCO contributes to relative reduction in the concentrations. However, Cheras station shows highest reduction in both $\mathrm{CO}(30.52 \%)$ and $\mathrm{NO}_{2}$ $(65.56 \%)$ concentrations. This is consistent with findings from previous study, which revealed that motor vehicle and soil dust dominated the composition of $\mathrm{PM}_{2.5}, \mathrm{NO}_{2}$, and $\mathrm{CO}$ in the urban setting (Dominic et al., 2012; Filonchyk and Hurynovich, 2020; Kanniah et al., 2020). Stations located in the most southern part of Peninsular, Larkin and Pasir Gudang both located in the state of Johor, show negligible change in the $\mathrm{PM}_{2.5}$ concentrations when compared between before MCO with during MCOs. This is due to the increase in $\mathrm{PM}_{2.5}$ concentration to $15.10 \mu \mathrm{g} \mathrm{m}^{-3}$ for Larkin station and to $12.41 \mu_{g^{-3}}^{-3}$ for Pasir Gudang station during MCO P3 higher than concentrations before $\mathrm{MCO}$ which recorded $14.3 \mu \mathrm{g} \mathrm{m}^{-3}$ and $10.6 \mu \mathrm{g} \mathrm{m} \mathrm{m}^{-3}$ in Larkin and Pasir Gudang station, respectively. However, both stations recorded significant reduction in $\mathrm{CO}$ and $\mathrm{NO}_{2}$ concentrations, suggesting the contribution of MCO to the quality of air in this region. Concentrations of $\mathrm{PM}_{2.5}$ in station located at East Peninsular region, Kuala Terengganu, Terengganu show less variations which may be contributed by sea salt due to the location of this city close to the beach. However, this station show noticeable reduction $(p<0.05)$ in $\mathrm{NO}_{2}(43.63 \%)$ and $\mathrm{SO}_{2}(22.43 \%)$, suggesting that emission in Kuala Terengganu is still affected by economy-related emission even though the reduction is a bit lower when compared to the other region. Kuching station which located in Sarawak region show no change in $\mathrm{PM}_{2.5}$, $\mathrm{CO}$, and $\mathrm{SO}_{2}$ concentrations and this is attributed to the initially low concentration in this area throughout the study period.

For industrial setting, significant air quality improvement was observed in stations located at north and east regions with relative reduction range from $24.0 \%$ to $-44.5 \%$ ( $p<$ 0.05 ) in daily $\mathrm{PM}_{2.5}$ concentration during $\mathrm{MCO}$ phases with highest reduction was found in Kulim, Kedah station which is located at northern part of Peninsular Malaysia. This is again consistent with findings from sub-urban and urban stations, which also exhibit highest reduction in stations located at north Peninsular. The reduction was more than $20 \%$ during MCO when compared with pre-MCO with

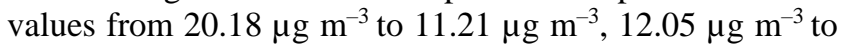
$9.15 \mu \mathrm{g} \mathrm{m}^{-3}, 16.47 \mu \mathrm{g} \mathrm{m}^{-3}$ to $11.27 \mu \mathrm{g} \mathrm{m}^{-3}$, and $10.40 \mu \mathrm{g} \mathrm{m}^{-3}$ to $7.83 \mu \mathrm{g} \mathrm{m}^{-3}$ for Kulim in Kedah, Balok Baru in Pahang, and Kemaman and Paka both in Terengganu stations, respectively (Table $\mathrm{S} 4$ ). Highest reduction of $\mathrm{NO}_{2}$ and $\mathrm{SO}_{2}$ was recorded in Balok Baru station where there are manufacturing and industrial hub located closed to the air quality station and was partially closed during MCO phase (Rosman et al., 2019). Pengerang station, which is located in south region (Johor), shows no changes in $\mathrm{PM}_{2.5}$ and $\mathrm{NO}_{2}$ concentration when compared to before MCO. This is because Pengerang is a new industrial area with lots of constructions still going on; hence the concentration shall be increased by the constructions byproduct or debris. Kimanis station which is located in Sabah and Samalaju station which is located in Sarawak also recorded no change in the concentrations of $\mathrm{PM}_{2.5}$ due to a very small variations in average concentration during MCOs compared to before MCO with measurement values from $10.45 \mathrm{\mu g} \mathrm{m}^{-3}$ to $10.65 \mu \mathrm{g} \mathrm{m}^{-3}$ for Kimanis station $(+1.99 \%)$ and from $10.84 \mu \mathrm{g} \mathrm{m}^{-3}$ to $9.81 \mu \mathrm{g} \mathrm{m}^{-3}$ for Samalaju station $(-9.52 \%)$ (Table S4). However, Kimanis 
Table 5. Relative change (\%) of: $\mathrm{PM}_{2.5}, \mathrm{CO}, \mathrm{NO}_{2}$, and $\mathrm{SO}_{2}$ for selected sub-urban, urban, industrial and rural stations during $\mathrm{MCO}$ with respect to pre-MCO.

\begin{tabular}{|c|c|c|c|c|c|}
\hline \multirow{2}{*}{ Stations } & \multirow{2}{*}{ Region } & $\mathrm{PM}_{2.5}\left(\mu \mathrm{g} \mathrm{m}^{-3}\right)$ & $\mathrm{CO}(\mathrm{ppm})$ & $\mathrm{NO}_{2}(\mathrm{ppm})$ & $\mathrm{SO}_{2}(\mathrm{ppm})$ \\
\hline & & $\%$ & $\%$ & $\%$ & $\%$ \\
\hline \multicolumn{6}{|l|}{ Sub-urban } \\
\hline Alor Setar & $\mathrm{N}$ & $-43.93^{+}$ & -3.23 & $-35.43^{+}$ & $-24.26^{+}$ \\
\hline Sg Petani & $\mathrm{N}$ & $-37.71^{+}$ & $-26.10^{+}$ & $-38.94^{+}$ & $10.56^{+}$ \\
\hline Taiping & $\mathrm{N}$ & $-53.47^{+}$ & -17.04 & $-52.38^{+}$ & -2.66 \\
\hline Batu Muda KL & $\mathrm{C}$ & -17.02 & $-27.55^{+}$ & $-67.16^{+}$ & $-33.67^{+}$ \\
\hline Petaling Jaya & $\mathrm{C}$ & $-35.47^{+}$ & $-53.43^{+}$ & $-68.26^{+}$ & $-23.80^{+}$ \\
\hline Banting & $\mathrm{C}$ & $-24.34^{+}$ & $-35.12^{+}$ & $-42.52^{+}$ & $-15.29^{+}$ \\
\hline Nilai & $\mathrm{S}$ & $-32.93^{+}$ & $-26.68^{+}$ & $-49.44^{+}$ & $-20.62^{+}$ \\
\hline Port Dickson & S & $-25.37^{+}$ & $-12.05^{+}$ & $-46.90^{+}$ & $-51.83^{+}$ \\
\hline Besut & $\mathrm{E}$ & -7.89 & $-23.53^{+}$ & -23.3 & $-26.42^{+}$ \\
\hline Tanah Merah & $\mathrm{E}$ & $-17.87^{+}$ & -18.72 & $-44.85^{+}$ & $-22.04^{+}$ \\
\hline Kota Bharu & $\mathrm{E}$ & 2.4 & -4.91 & $-28.04^{+}$ & $-29.27^{+}$ \\
\hline Tawau & $\mathrm{Sb}$ & -4.23 & $10.34^{+}$ & $-36.46^{+}$ & $-15.49^{+}$ \\
\hline Kota Kinabalu & $\mathrm{Sb}$ & -20.51 & $8.64^{+}$ & $-62.21^{+}$ & $-52.73^{+}$ \\
\hline Labuan & $\mathrm{L}$ & 12.47 & $-37.65^{+}$ & $-35.78^{+}$ & $24.28^{+}$ \\
\hline Sibu & $\mathrm{Sr}$ & $-14.98^{+}$ & -9.96 & $-49.35^{+}$ & $17.34^{+}$ \\
\hline \multicolumn{6}{|l|}{ Urban } \\
\hline Seberang Jaya & $\mathrm{N}$ & $-40.51^{+}$ & $-28.95^{+}$ & $-46.46^{+}$ & $-13.63^{+}$ \\
\hline Minden & $\mathrm{N}$ & $-46.43^{+}$ & $-22.17^{+}$ & $-49.79^{+}$ & -4.24 \\
\hline TasekIpoh & $\mathrm{N}$ & $-27.83^{+}$ & $-25.37^{+}$ & $-60.62^{+}$ & -2.99 \\
\hline Cheras & $\mathrm{C}$ & $-32.06^{+}$ & $-30.53^{+}$ & $-65.56^{+}$ & $38.49^{+}$ \\
\hline Shah Alam & $\mathrm{C}$ & $-18.45^{+}$ & -25.92 & $-49.52^{+}$ & -13.12 \\
\hline Seremban & $\mathrm{S}$ & $-16.82^{+}$ & $-20.99^{+}$ & $-61.10^{+}$ & 25.19 \\
\hline Bandaraya Melaka & $\mathrm{S}$ & $-11.74^{+}$ & -5.83 & $-43.19^{+}$ & 10.09 \\
\hline Larkin & $\mathrm{S}$ & -6.34 & $-31.25^{+}$ & $-50.92^{+}$ & $8.45^{+}$ \\
\hline Pasir Gudang & $S$ & 1.5 & $-6.56^{+}$ & $-1.66^{+}$ & 13.22 \\
\hline Kuala Terengganu & $\mathrm{E}$ & -4.93 & -17.66 & $-43.63^{+}$ & $-22.43^{+}$ \\
\hline Kuching & $\mathrm{Sr}$ & -7.6 & 6.86 & $-39.71^{+}$ & 61.15 \\
\hline \multicolumn{6}{|l|}{ Industrial } \\
\hline Kulim & $\mathrm{N}$ & $-44.46^{+}$ & NA & $-44.33^{+}$ & 10.23 \\
\hline Pengerang & $\mathrm{S}$ & 23.18 & NA & 6.28 & $19.91^{+}$ \\
\hline Balok Baru & $\mathrm{E}$ & $-24.07^{+}$ & NA & $-51.85^{+}$ & -65.97 \\
\hline Kemaman & $\mathrm{E}$ & $-31.54^{+}$ & NA & $-19.02^{+}$ & 21.64 \\
\hline Paka & $\mathrm{E}$ & $-24.72^{+}$ & NA & 34.61 & $-2.92^{+}$ \\
\hline Kimanis & $\mathrm{Sb}$ & 1.99 & NA & $-46.38^{+}$ & $-5.24^{+}$ \\
\hline Samalaju & $\mathrm{Sr}$ & -9.52 & NA & -13.9 & 48.18 \\
\hline \multicolumn{6}{|l|}{ Rural } \\
\hline Seri Manjung & $\mathrm{N}$ & $-22.85^{+}$ & NA & NA & NA \\
\hline Kuala Selangor & $\mathrm{C}$ & $-8.16^{+}$ & NA & NA & NA \\
\hline Alor Gajah & $\mathrm{S}$ & -6.99 & NA & NA & NA \\
\hline Kluang & $S$ & -12.81 & NA & NA & NA \\
\hline Rompin & $\mathrm{E}$ & 32.74 & NA & NA & NA \\
\hline Limbang & $\mathrm{Sr}$ & $-16.69^{+}$ & NA & NA & NA \\
\hline Miri & $\mathrm{Sr}$ & $-22.14^{+}$ & NA & NA & NA \\
\hline Sarikei & $\mathrm{Sr}$ & $-29.91^{+}$ & NA & NA & NA \\
\hline
\end{tabular}

${ }^{+}$indicate average concentration before MCO vs. average concentration during MCOs significant at $\mathrm{p}<0.05$; NA: not available. Region: $\mathrm{N}=$ Northern, $\mathrm{C}=$ Central, $\mathrm{E}=$ Eastern, $\mathrm{S}=$ Southern, $\mathrm{Sb}=$ Sabah, $\mathrm{Sr}=\mathrm{Sarawak}$.

station shows notable reduction in $\mathrm{NO}_{2}$ and $\mathrm{SO}_{2}$ concentration. It is interesting to note that all pollutants in this setting do not exceed the guidelines from WHO and DOE before MCO and during $\mathrm{MCO}$.

$\mathrm{PM}_{2.5}$ decrease ration (\%) for rural stations are also presented in Table 5. There were no $\mathrm{CO}, \mathrm{NO}_{2}$, and $\mathrm{SO}_{2}$ data available for this setting. Overall, only $41.6 \%$ stations in this setting show considerable reduction $(p<0.05)$ of $\mathrm{PM}_{2.5}$ concentration between average concentrations pre-MCO with average concentrations during MCO. This could be due to rural areas is less populated, which may not be influenced by industrial or transportation related emissions. Nonetheless, 
$67 \%$ of stations located in rural setting recorded average $24-\mathrm{h}$ concentration less than $10 \mu \mathrm{g} \mathrm{m}^{-3}$ before $\mathrm{MCO}$, suggesting that these stations do not have significant local sources of pollution. The significant reduction was recorded in Seri Manjung, Perak station (-22.85\%), Kuala Selangor, Selangor station $(-8.16 \%)$, and Limbang $(-16.7 \%)$, Miri $(-22.14 \%)$, and Sarikei $(-29.91 \%)$ stations all in Sarawak. Other stations show no change in $\mathrm{PM}_{2.5}$ concentrations during $\mathrm{MCO}$ phases except for Rompin station. Rompin station which is located in the Pahang, east part of Peninsular Malaysia, shows gradual increase in $\mathrm{PM}_{2.5}$ concentration from $9.12 \mu \mathrm{g} \mathrm{m}^{-3}$ before MCO to $13.61 \mu \mathrm{g} \mathrm{m}^{-3}, 13.13 \mu \mathrm{g} \mathrm{m}^{-3}$, and $22.54 \mu \mathrm{g} \mathrm{m}^{-3}$ during MCO P1, MCO P2, and MCO P3, respectively. This could be due to illegal local biomass burning that occurred during the study period as observed from MODIS Active Fire data (Fig. 3). Fig. 3 clearly shows there were less hotspots detected in Rompin before MCO (blue circle) and the number of hotspots increased during MCO P1, MCO P2, and MCO P3. The concentration during MCO $\mathrm{P} 4$ reduced to $8.06 \mu \mathrm{g} \mathrm{m}^{-3}$ due to reduction of local fires in this area.

\section{CONCLUSIONS}

Our observation from 65 regulatory monitoring stations have clearly demonstrated the impact of economic and daily activities restriction through the implementation of COVID-19 $\mathrm{MCO}$ on the reduction of major air pollutants concentration in urban central regions in Malaysia. In contrast, moderate changes in reduction of $\mathrm{PM}_{2.5}, \mathrm{CO}$, and $\mathrm{NO}_{2}$ levels were observed at sub-urban, industrial, and rural stations from spatial and temporal variations. By comparing with MODIS Active Fire data, we found high number of hotspots fire during MCO P1 and reduce slowly after MCO P2 were observed. This may suggest as evidence of small changes in reduction of $\mathrm{PM}_{2.5}$ concentrations although the $\mathrm{MCO}$ measures have been introduced; however, the local biomass-burning activities still occur. Overall, $\mathrm{CO}$ and $\mathrm{NO}_{2}$ showed higher reduction during $\mathrm{MCO}$ in sub-urban and urban compared with pre-MCO. Nonetheless, $\mathrm{PM}_{2.5}, \mathrm{CO}$ and $\mathrm{NO}_{2}$ appeared to have similar diurnal and weekly pattern suggesting these concentrations may dominated by similar sources. There is no clear pattern of $\mathrm{SO}_{2}$ reduction suggesting that $\mathrm{SO}_{2}$ concentrations vary according to local setting and region. However, higher reduction can be observed in stations located in industrial setting. The meteorological parameters during MCO show no significant different and heterogeneous compared to before MCO suggesting improvement in air quality during $\mathrm{MCO}$ is attributed to indirect influence of COVID-19 control measures. The results from this study could lead to a further exploration on the factor affecting the air quality status through the region and could be an early indicative of a different policy implementation i.e., the vehicles restriction on a special temporal and spatial arrangements, revision on the threshold values of a certain air pollutant variables as well as a measure on a certain anthropogenic activities that lead to air quality deterioration through environment forensics investigation. The data observed throughout the stations can be used to serve as a comparative value under different regions, activities, and impact. Nevertheless, the health impact assessment could be mapped out and prioritized through different scenarios of temporal and spatial settings.

\section{ACKNOWLEDGMENTS}

The authors would also like to thank the Government of Malaysia for providing the data.

\section{DISCLAIMER}

Reference to any company or specific commercial products does not constitute financial and personal conflicts of interest.

\section{SUPPLEMENTARY MATERIAL}

Supplementary data associated with this article can be found in the online version at https://doi.org/10.4209/aaqr.2 020.06.0334

\section{REFERENCES}

Abdullah, S., Mansor, A.A., Napi, N., Mansor, W., Ahmed, A.N., Ismail, M. and Ramly, Z. (2020). Air quality status during 2020 Malaysia Movement Control Order (MCO) due to 2019 novel coronavirus (2019-nCoV) pandemic. Sci. Total Environ. 729: 139022. https://doi.org/10.1016/ j.scitotenv.2020.139022

Afroz, R., Hassan, M.N. and Ibrahim, N.A. (2003). Review of air pollution and health impacts in Malaysia. Environ. Res. 92: 71-77. https://doi.org/10.1016/S0013-9351(02)00059-2

Ahmad, A. (2020, July 1). Perintah Kawalan Pergerakan digazet, hukuman 6 bulan penjara, tambahan sektor penting. http://www.astroawani.com/berita-malaysia/peri ntah-kawalan-pergerakan-digazet-hukuman-6-bulan-penj ara-tambahan-sektor-penting-234108

Amil, N., Mohd, T.L., Md, F.K. and Mohamad, M. (2016). Seasonal variability of $\mathrm{PM}_{2.5}$ composition and sources in the Klang Valley urban-industrial environment. Atmos. Chem. Phys. 16: 5357-5381. https://doi.org/10.5194/acp16-5357-2016

Ashaari, Z.H., Bigg, G.R. and Bryant, R.G. (2014). Patterns of Aerosol Over Malaysia from Multiple Satellite-Borne Sensors. In: From Sources to Solution, Aris A., Tengku Ismail, T., Harun, R., Abdullah, A. and Ishak, M. (Eds.), Springer, Singapore.

Awang, M.B., Jaafar, A.B., Abdullah, A.M., Ismail, M.B., Hassan, M.N., Abdullah, R., Johan, S. and Noor, H. (2000). Air quality in Malaysia: Impacts, management issues and future challenges. Respirology 5: 183-196. https://doi.org/10.1046/j.1440-1843.2000.00248.x

Azmi, S.Z., Latif, M.T., Ismail, A.S., Juneng, L. and Jemain, A.A. (2010). Trend and status of air quality at three different monitoring stations in the Klang Valley, Malaysia. Air Qual. Atmos. Health 3: 53-64. https://doi.org/10.1007/ s11869-009-0051-1

Bernama (2020a, August 1). Enhanced Movement Control Order (EMCO). https://www.bernama.com/en/infographi cs/index.php?v=5886 
Bernama (2020b, August 1). Essence of Conditional Movement Order (CMCO). https://web.archive.org/web/ 20200502065534/https://www.bernama.com/en/general/ news.php?id=1837487

Bunyan, J. (2020, June 1). PM: Malaysia under movement control order from Wed until March 31, all shops closed except for essential services. https://www.malaymail.com/n ews/malaysia/2020/03/16/pm-malaysia-in-lockdown-fromwed-until-march-31-all-shops-closed-except-for/1847204

Chan, J.F., Yuan, S. and Kok, K.H. (2020). A familial cluster of pneumonia associated with the 2019 novel coronavirus indicating person-to-person transmission: A study of a family cluster. Lancet 395: 514-523. https://doi.org/10.1016/S0140-6736(20)30154-9

Chen, Q.X., Huang, C.L., Yuan, Y. and Tan, H.P. (2020). Influence of COVID-19 Event on air quality and their association in mainland China. Aerosol Air Qual. Res. 20: 1541-1551. https://doi.org/10.4209/aaqr.2020.05.0224

Collivignarelli, M.C., Abbà, A., Bertanza, G., Pedrazzani, R., Ricciardi, P. and Carnevale Miino, M. (2020). Lockdown for CoViD-2019 in Milan: What are the effects on air quality? Sci. Total Environ. 732: 139280. https://doi.org/10.1016/j.scitotenv.2020.139280

Dantas, G., Siciliano, B., França, B.B., da Silva, C.M. and Arbilla, G. (2020). The impact of COVID-19 partial lockdown on the air quality of the city of Rio de Janeiro, Brazil. Sci. Total Environ. 729: 139085. https://doi.org/1 0.1016/j.scitotenv.2020.139085

Dominick, D., Juahir, H., Latif, M.T., Zain, S.M. and Aris, A.Z. (2012). Spatial assessment of air quality patterns in Malaysia using multivariate analysis. Atmos. Environ. 60: 172-181. https://doi.org/10.1016/j.atmosenv.2012.06.021

Dutheil, F., Baker, J.S. and Navel, V. (2020). COVID-19 as a factor influencing air pollution? Environ. Pollut. 263: 114466. https://doi.org/10.1016/j.envpol.2020.114466

Ee-ling, O., Mustaffa, N.I., Hamizah, Amil, N., Khan, M.F. and Latif, M.T. (2015). Source contribution of $\mathrm{PM}_{2.5}$ at different locations on the Malaysian Peninsula. Bull. Environ. Contam. Toxicol. 94: 537-542. https://doi.org/1 0.1007/s00128-015-1477-9

Filonchyk, M. and Hurynovich, V. (2020). Spatial distribution and temporal variation of atmospheric pollution in the South Gobi Desert, China, during 2016-2019. Environ. Sci. Pollut. Res. 27: 26579-26593. https://doi.org/10.100 7/s11356-020-09000-y

Filonchyk, M., Hurynovich, V., Yan, H., Gusev, A. and Shpilevskaya, N. (2020). Impact assessment of COVID-19 on variations of $\mathrm{SO}_{2}, \mathrm{NO}_{2}, \mathrm{CO}$ and $\mathrm{AOD}$ over east China. Aerosol Air Qual. Res. 20: 1530-1540. https://doi.org/10. 4209/aaqr.2020.05.0226

Google LLC. (2020, August 2). COVID-19 community mobility report. https://www.google.com/covid19/mobi lity

Ismail, A.S. Abdullah, A.M and Samah, M.A.A. (2017). Environmetric study on air quality pattern for assessment in northern region of Peninsular Malaysia. J. Environ. Sci. Technol. 10: 186-196. https://doi.org/10.3923/jest.2017. 186.196

Kanniah, K.D., Kamarul Zaman, N.A.F., Kaskaoutis, D.G. and Latif, M.T. (2020). COVID-19's impact on the atmospheric environment in the Southeast Asia region. Sci. Total Environ. 736: 139658. https://doi.org/10.1016/ j.scitotenv.2020.139658

Khan, M.F., Latif, M.T., Saw, W.H., Amil, N., Nadzir, M.S.M., Sahani, M., Tahir, N.M. and Chung, J.X. (2015). Fine particulate matter in the tropical environment: Monsoonal effects, source apportionment, and health risk assessment. Atmos. Chem. Phys. 16: 597-617. https://doi.org/10.5194/acp-16-597-2016

Latif, M.T., Dominick, D., Ahamad, F., Khan, M.F., Juneng, L., Hamzah, F.M. and Nadzir, M.S.M. (2014). Long term assessment of air quality from a background station on the Malaysian peninsula. Sci. Total Environ. 482: 336-348. https://doi.org/10.1016/j.scitotenv.2014.02.132

Latif, M.T., Othman, M., Idris, N., Juneng, L., Abdullah, A.M., Hamzah, W.P., Khan, M.F., Sulaiman, N.M.N., Jewaratnam, J., Aghamohammadi, N., Sahani, M., Chung, J.X., Ahamad, F., Amil, N., Darus, M., Varkkey, H., Tangang, F. and Jaafar A.B. (2018) Impact of regional haze towards air quality in Malaysia: A review. Atmos. Environ. 177: 28-44. https://doi.org/10.1016/j.atmosenv.2018.01.002

Li, J. and Tartarini, F. (2020). Changes in air quality during the COVID-19 lockdown in Singapore and associations with human mobility trends. Aerosol Air Qual. Res. 20: 1748-1758. https://doi.org/10.4209/aaqr.2020.06.0303

Md Shah, A.U., Safri, S.N.A., Thevadas, R., Noordin, N.K., Abd Rahman, A., Sekawi, Z., Ideris, A. and Hameed Sultan, M.T. (2020). COVID-19 outbreak in Malaysia: Actions taken by the Malaysian government. Int. J. Infect. Dis. 97: 108-116. https://doi.org/10.1016/j.ijid.2020.05.093

Mohd Nadzir, M.S., Ooi, M.C.G., Alhasa, K.M., Bakar, M.A.A., Mohtar, A.A.A., Nor, M.F.F.M., Latif, M.T., Hamid, H.H.A., Ali, S.H.M., Ariff, N.M., Anuar, J., Ahamad, F., Azhari, A., Hanif, N.M., Subhi, M.A., Othman, M. and Nor, M.Z.M. (2020). The Impact of movement control order (MCO) during pandemic COVID-19 on local air quality in an urban area of Klang Valley, Malaysia. Aerosol Air Qual. Res. 20: 1237-1248. https://doi.org/10.4209/aaqr.2020.04.0163

Mohtar, A.A.A., Latif, M.T., Baharudin, N.H., Ahamad, F., Chung, J.X., Othman, M. and Juneng, L. (2018). Variation of major air pollutants in different seasonal conditions in an urban environment in Malaysia. Geosci. Lett. 5: 21. https://doi.org/10.1186/s40562-018-0122-y

Navinya, C., Patidar, G. and Phuleria, H.C. (2020). Examining effects of the COVID-19 national lockdown on ambient air quality across urban India. Aerosol Air Qual. Res. 20: 1759-1771. https://doi.org/10.4209/aaqr.2 020.05.0256

Pascarella, G., Strumia, A., and Piliego, C., Bruno, F., Del Buono, R., Costa, F., Scarlata, S. and Agrò, F.E. (2020). COVID-19 diagnosis and management: A comprehensive review. J. Intern Med. 288: 192-206. https://doi.org/10.1 111/joim. 13091

Prime Minister's Office (2020a, August 1). Kenyataan Media MKN: Perincian Perintah Kawalan Pergerakan. https://www.pmo.gov.my/2020/03/kenyatan-media-mkn18-mac-2020/ 
Prime Minister's Office (2020b, August 1). Restriction of Movement Order. https://www.pmo.gov.my/2020/03/mo vement-control-order/

Rosman, P.S., Abu Samah, M.A. and Yunus, K. (2019). A Research on Concentration and Distribution of Airborne Particulate Matter in Kuantan City. Int. J. Recent Technol. Eng. 8: 288-292. https://doi.org/10.35940/ijrte.B1050.07 $82 \mathrm{~S} 319$

Şahin, Ü.A. (2020). The effects of COVID-19 measures on air pollutant concentrations at urban and traffic sites in Istanbul. Aerosol Air Qual. Res. 20: 1874-1885. https://doi.org/10.4209/aaqr.2020.05.0239

Sharma, S., Zhang, M., Anshika, Gao, J., Zhang, H. and Kota, S.H. (2020). Effect of restricted emissions during COVID-19 on air quality in India. Sci. Total Environ. 728: 138878. https://doi.org/10.1016/j.scitotenv.2020.13 8878

Suhaimi, N.F., Jalaludin, J. and Latif, M.T. (2020). Demystifying a possible relationship between COVID19, air quality and meteorological factors: Evidence from Kuala Lumpur, Malaysia. Aerosol Air Qual. Res. 20: 1520-1529. https://doi.org/10.4209/aaqr.2020.05.0218

Tahir, N.M., Koh, M. and Suratman, S. (2013). PM $_{2.5}$ and associated ionic species in a sub-urban coastal area of Kuala Terengganu, Southern South China Sea (Malaysia). Sains Malays. 42: 1065-1072.

Venter, Z.S., Aunan, K., Chowdhury, S. and Lelieveld, J. (2020). COVID-19 lockdowns cause global air pollution declines with implications for public health risk. medRxiv.
2020.04.10.20060673. https://doi.org/10.1101/2020.04.1 0.20060673

Wong, D., Yuan, L. and Perlin, S. (2004). Comparison of spatial interpolation methods for the estimation of air quality data. J. Exposure Sci. Environ. Epidemiol. 14: 404-415. https://doi.org/10.1038/sj.jea.7500338

World Health Organization (WHO) (2020a, August 1). WHO Director-General's remarks at the media briefing on 2019-nCoV on 11 February 2020. https://www.who.int/d $\mathrm{g} /$ speeches/detail/who-director-general-s-remarks-at-themedia-briefing-on-2019-ncov-on-11-february-2020

World Health Organization (WHO) (2020b, August 1). Statement on the second meeting of the International Health Regulations (2005) Emergency Committee regarding the outbreak of novel coronavirus (2019-nCoV). https://www.who.int/news-room/detail/30-01-2020-state ment-on-the-second-meeting-of-the-international-healthregulations-(2005)-emergency-committee-regarding-theoutbreak-of-novel-coronavirus-(2019-ncov)

World Health Organization (WHO) (2020c, August 1). Coronavirus disease (COVID-19) Situation Report-192. https://www.who.int/docs/default-source/coronaviruse/si tuation-reports/20200730-covid-19-sitrep-192.pdf?sfvrs $\mathrm{n}=5 \mathrm{e} 52901 \mathrm{f} \_8$

Received for review, June 21, 2020

Revised, August 8, 2020

Accepted, August 19, 2020 